\title{
Ruptured Lung Hydatid Cyst in Late Pregnancy that Mimics Tension Hydropneumothorax
}

\author{
Hamileliğin Geç Döneminde Tansiyon Hidropnömotoraksı Taklit Eden \\ Rüptüre Akciğer Kist Hidatiği
}

Cumhur Murat Tulay', Ahmet Ceylan²

\begin{abstract}
Respiratory failure and hemodynamic instability are responsible for up to $80 \%$ of the obstetric admissions to the intensive care unit. We report an unusual case of a multigravida with ruptured pulmonary hydatid cyst that mimics tension hydropneumothorax.
\end{abstract}

Key words: Hydatid cyst at pregnancy, tension hydropneumothorax, obstetric emergency.

\section{Özet}

Solunum yetmezliği ve hemodinamik anstabilite, obstetrik yoğun bakım yatışlarının \%80'ninden sorumludur. Biz burada çok nadir karşılaşılan multigravid hastada hamileliğin geç döneminde tansiyon hidropnömotoraksı taklit eden rüptüre akciğer kist hidatiği sunduk.

Anahtar Sözcükler: Hamilelikte hidatik kist, tansiyon hidropnömotoraks, obstetrik acil.
Hydatid disease in pregnancy is a rare condition, with and incidence of $1 / 20,000$ to $1 / 30,000$ deliveries $(1,2)$. In late pregnancy, it carries the risk of enlargement with subsequent rupture and anaphylactic shock (3). Respiratory failure and hemodynamic instability are responsible for up to $80 \%$ of the obstetric admissions to the intensive care unit (4). We report an unusual case of a multigravida with ruptured pulmonary hydatid cyst that mimics tension hydropneumothorax.

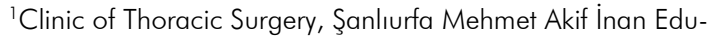
cation and Research Hospital, Sanlıurfa, Turkey

${ }^{2}$ Clinic of Emergency Medicine, Şanlıurfa Mehmet Akif İnan

Education and Research Hospital, Şanlıurfa, Turkey

'Şanlıurfa Mehmet Akif İnan Eğitim ve Araşııma Hastanesi, Göğüs Cerrahi Kliniği, Sanlıurfa

${ }^{2}$ Şanlıurfa Mehmet Akif İnan Eğitim ve Araştırma Hastanesi, Acil Kliniği, Şanlıurfa
}

Submitted (Başvuru tarihi): 10.09.2013 Accepted (Kabul tarihi): 12.11.2013

Correspondence (iletişim): Cumhur Murat Tulay, Clinic of Thoracic Surgery, Şanlıurfa Mehmet Akif İnan Education and Research Hospital, Şanlıurfa, Turkey

e-mail: cumhurtulay@hotmail.com 


\section{CASE}

A 21 -year-old patient with multigravida, at 34 weeks of gestation, presented with syncope, vomiting, and respiratory failure. She explained that the symptoms had been present for ten days. She had gone to some medical centers, but the doctors diagnosed her symptoms as being related to the last trimester of pregnancy. There was not any thoracic imaging up to now. The patient's physical examination revealed severe respiratory distress with a respiratory rate of 35 breaths/min, tachycardia of 160 $183 / \mathrm{min}$, fever of $38.0{ }^{\circ} \mathrm{C}$, blood pressure of $90 / 60$ $\mathrm{mmHg}$, and no breath sounds at the left hemithorax. Oxygen saturation was $90 \%$ with a facemask at $10 \mathrm{~L} / \mathrm{min}$. The chest $x$-ray that was taken on presentation to the referring hospital revealed a high air-fluid level, which was surrounded by a thick membrane in the left hemithorax with the sliding of the trachea and heart to the right hemithorax, which mimics tension hydropneumothorax (Figure 1). Thoracentesis was carefully conducted to exclude hydropneumothorax, and neither fluid nor air was aspirated from the left hemithorax. A decision was made to proceed with a caesarian section, followed by left thoracotomy to save both the mother and the baby. Informed consent was obtained from patient. Following the caesarian section, a left thoracotomy was performed. A destroyed left lower lobe and huge ruptured hydatid cyst were detected. A left lower lobectomy was performed. The baby was sent to another hospital for admission to the pediatric intensive care unit. The mother was discharged from the hospital nine days after surgery without any complications.

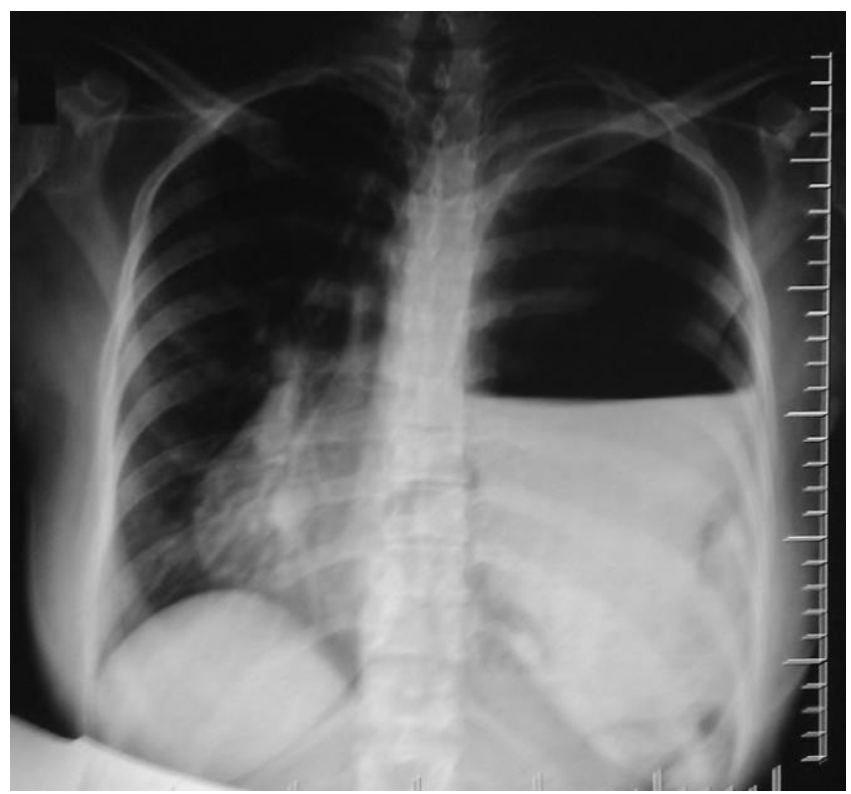

Figure 1: Ruptured cystic structure with right side mediastinal deviation

\section{DISCUSSION}

A hydatid cyst is a kind of parasitosis, which affects mostly liver and/or lungs. It can cause different symptoms or be found incidentally. Cough, hemoptysis, and chest pain are the most common symptoms of hydatid cyst of the lung (5). There are very few cases about pregnancy and coexistence with hydatid cyst in literature $(1,2,5,7)$. In the current case, we determined a ruptured hydatid cyst of the lung in the late period of pregnancy with respiratory failure.

Cysts may rupture spontaneously or more commonly precipitated by a sudden rise in intrapulmonary pressure (6). It may follow an increase in intraabdominal pressure as in pregnancy (7).

Radiologically, an intact cyst typically presents as a round or oval homogenous density with sharp margins. In case of a ruptured cyst, the solid component may fall into the cavity (mass within a cavity) (8). The current case revealed a high air-fluid level in the left hemithorax with sliding of the trachea and heart to the right hemithorax. A solid component of the cyst was not seen on the chest $X$-ray and it could be confused with tension hydropneumothorax in emergency conditions.

Pregnancy and pulmonary hydatidosis occurring together are very rare and there is no consensus on standard approach (7). The researchers of the current study believe that definitive management of ruptured pulmonary hydatid cyst is surgery.

Ruptured pulmonary hydatid cyst should be considered in patients living in endemic areas with suggestive radiologic findings, especially during pregnancy. Doctors should be alert for the patients who live in endemic areas for hydatid cyst and receive a chest $x$-ray before planning pregnancy.

\section{CONFLICTS OF INTEREST}

None declared.

\section{AUTHOR CONTRIBUTIONS}

Concept - C.M.T., A.C.; Planning and Design - C.M.T., A.C.; Supervision - C.M.T., A.C.; Funding - C.M.T., A.C.; Materials - C.M.T., A.C.; Data Collection and/or Processing - C.M.T., A.C.; Analysis and/or Interpretation C.M.T., A.C.; Literature Review - C.M.T., A.C.; Writing C.M.T., A.C.; Critical Review - C.M.T., A.C.

\section{YAZAR KATKILARI}

Fikir - C.M.T., A.C.; Tasarım ve Dizayn - C.M.T., A.C.; Denetleme - C.M.T., A.C.; Kaynaklar - C.M.T., A.C.; 
Malzemeler - C.M.T., A.C.; Veri Toplama ve/veya İşleme - C.M.T., A.C.; Analiz ve/veya Yorum - C.M.T., A.C.; Literatür Taraması - C.M.T., A.C.; Yazıyı Yazan - C.M.T., A.C.; Eleştirel İnceleme - C.M.T., A.C.

\section{REFERENCES}

1. Fekih MA, Abed A, Chelli H, Khrouf M, Chelli M. Pelvic hydatid cyst and pregnancy. Four cases. J Gynecol Obstet Biol Reprod (Paris) 1992; $21: 803-5$.

2. Golaszewski T, Susani M, Golaszewski S, Sliutz G, Bischof $G$, Auer H. A large hydatid cyst of the liver in pregnancy. Arch Gynecol Obstet 1995; 256:43-7. [CrossRef]

3. Koul PA, Koul AN, Wahid A, Mir FA. CT in pulmonary hydatid disease: unusual appearances. Chest 2000; 118:1645-7. [CrossRef]
4. Campbell LA, Klocke RA. Implications for the pregnant patient. Am J Respir Crit Care Med 2001; 163:1051-4. [CrossRef]

5. Tertemiz KC, Gökçen B, Önen A, Akkoçlu A. Gebelik ve kist hidatik. Tüberküloz ve Toraks Dergisi 2008; 56:96-9.

6. Morar R, Feldman C. Pulmonary echinococcosis. Eur Respir J 2003; 21:1069-77. [CrossRef]

7. Ekim H, Ekim M. Echinococcal tension pneumothorax in a pregnant woman. Pak J Med Sci 2009; 25:159-61.

8. Pedrosa I, Saiz A, Arrazola J, Ferreiros J, Pedrosa CS. Hydatid disease: radiologic and pathologic features and complications. Radiographics 2000; 20:795-817. 